\title{
DIE RYKDOM VAN DIE SUID-AFRIKAANSE BODEM
}

E.k is gevra om u binne die kurt bestek van veertig minute loe te spreek our die rykdom van die Suid-Afrikaanse bodem.

Die vraag is nou eerstens wat 'n mens onder rykdom van boden moet verstaun. Volgens die woordeboek beteken rykdom ook welstand of vermoë. Volgens Schumann en andere 11957, 2-3. 43 en 51 , word rykdom bepaal deur die produksie van kapitaalgoedere en die vermeerdering van kapitaalbates. Elke land se produksiestelsel word beïnvloed deur die aan- of afwesigheid van natuurlike hulpbronne en, aangesien hierdie produksiemiddele gewoonlik van beperkte omvang is. is dit by enige produksie-underneming essensieel dat die produksie so doeltreffend of ekonomies moontlik gemaak moet word.

Sedert ongeveer een honderd jaar gelede is die produksic van kapitaalgoedere in Suid-Afrika steeds meer op die natuurlike hulpbronne van ons eie bodem gebaseer. Sover dit ons delfstowwe betref. was dit oor die algemeen redelik maklik om ekonomies te produseer en sudoende ons volksvermoë of rykdom te vermeerder. Wat dit betref, kan ons dus sê dat ons hodem wel ryk is. Maar die gehalte van ons grond en reënval maak dit moeilik om landbouproduksie, veral op akkerboukundige gebied. ekonomies doeltreffend te hou en in dié opsig is ons hodem seker minder ryk, as dit nie selfs arm is nie.

Tweedens ontstaan die vraag nou hoe 'n mens rykdom van bodem moet meet of bepaal. Meeste persone sou sekcr antwoord dat rykdom in terme van monetêre of ekonomiese waarde gemeet moet word. Volgens Schumann (1963, 3) tel natuurlike hulpbronne onder die vernaamste van daardie faktore wat die welvaart van 'n land op die lang duur bepaal 'n wat in '" hoë mate .,meethaar" is. Ek meen egter dat rykdom ook in welstand of vermoë mag inhou wat nie direk op in monetêre wyse gemeet kan word nie. en in dié verhand dink 
ek veral aan ons waterhulpbronne en die produksievermoë van ons gronde.

In die lig van hierdie standpunt wil ek dan daardie hulp. bronnc wat die rykdom van onk Suid-Afrikaanse bodem bepaal, indeel in:

(a) nie-hernieubare delfstowwe, waarvan die waarde heste in terme van verkoopswaarde of ekonomiese potensiaal gemeet kan word; en

(b) hernieubare bodembronne, waarvan die waarde miskien beste in terme van noodsaaklikheid vir voortbestaan en ontwikkeling gemeet kan word.

Onder die eerste afdeling kan ons insluit minerale delfstowwe, soos goud. diamante, mangaanerts, ystererts, ens., asook fossiel-brandstowwe, soos steenkool. Die tweede afdeling het hetrekking op grond- en waterhulpbronne.

Sover dit die delfstowwe betref, blyk die rykdom van ons budem waarskynlik beste uit 'n oorsig van die ontwikkeling van die mynbou. sy bydrae tot die volksinkomste met die loop van tyd en sy stabiliserende invloed op die landsekonomie. Daarbenewens moet dan ook nog in berekening gebring word die stimulerende uitwerking van die mynbou op sekondêre nywerhede. vervoer en werkvoorsiening. Die rykdom. of eerder armoede. van ons land aan die hernieubare hulpbronne, water en grond. blyk miskien beste uit in oorsig van die akkerboukundige ell pastorale bydraes tot ons volksinkomste oor die jare en die probleme van onekonomiese produksie en grond- ell watcrbewaring waarvoor ons vandag te staan ge$\mathrm{knm}$ het.

Verskeit deskundiges het in die afgelope tyd daarop yewys dat ons land geen werklike rol in die wêreldekonomie yespcel het roor die ontdekking van diamante in 1867 en goud in 1886 nie (Andrews en andere, 1962, 4-6; Busschau, 1961, 10; Liebenberg en Lambooy. 1961, 398). Afgesien daarvan dat hierdie ontdekkings gelei het tot die ontstaan van ons mynbedryf. het hulle ook aanleiding gegee tot die ontstaan van elektriese kragopwekking en die aanleg van 'n binnelandse sporwegnetwerk (Andrews en andere, 1962, 5-6; Diu Plessis. 1961. 89). Vandag is Suid-Afrika die vernaamste nineraalproduserende land in die suidelike halfrond (Van Royen en Bowles, 1952, 3-4). 
Tot die Tweede Wêreldoorlog was ons ekonomie hoofsaaklik gebaseer op mynbou, akkerbou en veeteelt, maar sedertdien het daar 'n groot omwenteling gekom, gekenmerk deur die verbasende groei van die fabriserende nywerhede (Busschau, 1961, 11-12; Norval, 1962, 2-4, 39 en 139). Ons weet vandag in watter hulpbronne die krag van ons ekonomie lê, maar ons weet ook watter minder oorvloedige hulpbronne reeds 'n stremmende invloed op ons ekonomiese groei het of in die toekoms gaan hê. Dit het nou baie noodsaaklik geword dat ons volksleiers op ekonomiese, industriële en landboukundige gebied 'n voorraadsopname van ons volkshuishouding maak met die oog op beplanning van die gesonde en selfstandige ekonomiese groei van ons land in die toekoms. Sodanige beplanning behoort in die eerste plek toegespits te wees op die voordeligste ontginning, verwerking, bemarking en verbruik van beide oorvloedige en skaars hulpbronne in ons land. Reeds 14 jaar gelede het mnr. E. H. Louw, destyds Minister van Ekonomiese Sake, (1949, 38-39) gesê:

„The broad objective in the formulation of a national economic policy should, I think, be the utilisation of our natural resources in such a manner that they will yield to as many people as possible, now and in the years to come, the opportunity to live on as high a standard as possible.

"In order to achieve that objective it is necessary to build an economy based on our most permanent resources. The labour of our people, assisted by our gold, coal, iron, and other minerals, as well as our agricultural and other resources, must be our primary product and the basis of our economy."

In hierdie verband wys Norval (1962, 25 en 46) en Koch (1962, 10-11) daarop dat opgeleide mannekrag een van ons vernaamste, maar tans nog skaarste hulpbronne is. Norval $(1962,25)$ sê:

„South Africa needs one thing above all things, if it wishes to take advantage of the vast economic potential that lies dormant in the bowels of its territories; it must step up and step up rapidly its secondary and university training and adjust and direct it more towards the exploitation of the economic potential of the country. In particular the country should train scientists and engineers to a considerably greater 
extent and with much more deliberateness than has been the case up to the present."

Met die voorafgaande in gedagte wil ek nou 'n selektiewe oorsig, onder verskillende hoofde, probeer gee van sekere aspekte van ons volksinkomste en landsekonomie wat veral betrekking het op die ontginning, verwerking, bemarking en verbruik van ons minerale delfstowwe, ons fossiel-brandstowwe en ons grond- en waterhulpbronne oor die tydperk 1910-1960, met die idee dat dit moontlik kan help by die beoordeling van die relatiewe belangrikheid van hierdie hulpbronne vir ons toekomstige vooruitgang.

Dit kan miskien beste vergelykenderwys gedoen word deur syfers vir die jare 1910, 1930, 1950 en 1960 so na as moontlik aan te haal uit die onlangse publikasie van die Buro vir Sensus en Statistiek, „Uniestatistieke oor Vyftig Jaar” (1960). Hierdie jare dien as gerieflike en min of meer natuurlike skeidings tussen die vernaamste tydvakke in Suid-Afrika se ontwikkeling van Unifikasie tot Republiekwording. Die jaar 1930 val teen die einde van die ongunstige tydperk van inflasie na die Eerste Wêreldoorlog en dit kom ook naasteby ooreen met die eerste devaluasie van ons geld in 1932, die groot droogte van $1930-1933$ en die eerste produksie van staal deur Yskor in 1934. $\mathrm{Na}$ die devaluasie van 1932 het heide goudmynbou en die fabriserende nywerhede baie vinniger as ooit vantevore vooruitgegaan (Busschau, 1961, 11 ). Die jaar 1950 volg kort na die einde van die Tweede Wêreldoorlog en ons afstapping van die goudstandaard in 1948; dit val saam met die uitbreek van die Koreaanse oorlog en die stigting van Sasol en is net voor die vorming van Foskor in 1951 (Norval. 1962. 13, 33 en 37; Anoniem, 1961a, 4).

Volksinkomste: Ons bepaal ons hier net by volksinkomste verkry uit die ontginning cn verwerking van Suid-Afrikaanse delfstowwe en uil die hewerking van Suid-Afrikaanse grond.

In 1912 was die totale volksinkomste maar net R265.8 miljoen, d.w.s. minder as die helfte van wat die goudmynbou alleen tans per jaar lewer (Tegniek, 1963, 9). In 1930 het dit vermeerder tot R506.4 miljoen, in 1942 was dit vir die ecrste keer meer as R1000 miljoen en in 1950 het dit vir die cerste keer R2000 miljoen oortref. In 1959 was dit R4054 miljoen. 
Die persentuele aandele van landbou, mynbou en fabriekswose in hierdio volksinkomste het 8008 volg met die loop van tyd verander:

(a) Landbou (insluitende bosbou, landboubeheerrade, visserye, ens.) : Vir die eerste twee dekades na Unifikasie het landbou tussen 17 en 25 persent van die volksinkomste gelewer, maar in 1930 het landbou se bydrae gedaal tot 13.9 persent en daarna het dit min of meer so gebly. In 1950 was dit 13.1 persent en in 1959 was dit 11.7 persent.

(b) Mynbou (uitsluitende staatsdelwerye): In 1912 was die bydrae van mynbou tot die volksinkomste maar net 2.7 persent. Van die Eerste Wêreldoorlog tot 1930 het dit gewissel tussen 15 en 22 persent. Daarna, tot omtrent 1940, het dit op 'n effens hoër vlak gebly met 'n speling tussen 16 en 24 . persent, waarna dit geleidelik afgeneem het na 'n laagtepunt van ongeveer 10 persent in 1949. Sedert 1950 het dit gewissel tussen 10 en 14 persent en in 1959 was dit gelyk aan 13.3 persent.

(c) Febriekswese (insluitende slegs private fabriekswese en nie sulke organisasies soos die Randse Waterraad, Evkom, Sasol, Kop, ens. nie): In 1912 was die aandeel van fabriekswese in ons volksinkomste net 6.7 persent. In 1918 was dit 9.8 persent en daarna het dit geleidelik vermeerder tot 15.4 persent in 1930, 17.5 persent in 1940, 22.1 persent in 1950 en 24.6 persent in 1959.

In 1959 was die helfte van ons volksinkomste dus afkomstig uit die drie ekonomiese sektore, landbou, mynbou en fabriekswese, in die verhouding van $11.7: 13.3: 24.6$, vergeleke met 'n bietjie meer as 'n kwart (26.81 persent) in 1912 in die verhouding van $17.4: 2.71: 6.7$.

Norval $(1962,139-140)$ wys daarop dat die relatiewe groot toename in die bydrae van sekondêre nywerhede tot die volksinkomste, vergeleke met die toename in die bydraes van mynhou en landbou, 'n gevolg is van die baie groter uithreidingskoëffisiënt of -potensiaal van sekondêre nywerhede, vergeleke met mynbou of landbou. Busschau (1961, 11-12) meen dat die vinnige en indrukwekkende groei van sommige fabriserende nywerhede bevorder is deur die toenemende aanvraag as gevolg van die ontwikkeling van nuwe 
myne op die Verre Wesrand, in die Vrystaat en in die distrikte van Klerksdorp en Kinross. Sy mening is dat: „Those who have in the past 15 years talked with more enthusiasm than knowledge about the prospects of the manufacturing industry should ask themselves how, in the absence of these mines (en dit geld nie net vir die nuwe goudmyne nie), such additions to capital invested, exports and dividends could have been secured. They should also remember the effect of this vast development on the actual growth of manufacturing industry."

Die stimulerende invloed van die mynbou op die ontwikkeling van sekondêre nywerhede asook op landbou blyk miskien duidelikste daaruit dat, waar dit in 1910 byna al sy voorrade ingevoer het, die mynwese teen 1948 byna 70 persent en in 1960 meer as 90 persent plaaslik verkry het (Busschau, 1961, 11; Anderson, 1961, 3). In 1960 is voorrade aangekoop vir 'n bedrag van meer as R260 miljoen, waarvan meer as R40 miljoen bestee is aan mielies en mielieprodukte, d.w.s. omtrent 40 persent van 'n mielie-oes soos dié van 1958 wat 'n brutowaarde van ongeveer R102 miljoen gehad het (Anderson, 1961, 3; Busschau, 1961, 11; Von Maltitz, 1963, 18; Bur. Sens. Stat., 1960, I-23).

Mynbou: By die opening van die sesde kongres van die Geologiese Vereniging van Suid-Afrika op 4, Februarie 1963 het die Minister van Mynwese, dr. N. Diederichs, daarop gewys dat die totale waarde van ons land se mineraleproduksie reeds meer as R15 miljard bedra (Een miljard $=10^{\circ}$ ). Die grootste deel hiervan is gedurende die afgelope $\mathbf{5 0}$ jaar gelewer. Die belangrike aandeel van die goudmynbedryf in hierdie inkomste uit minerale is duidelik uit die feit dat tot 1960 goudproduksie alleen verantwoordelik was vir omtrent R10 miljard en dat dit in 1962 alleen byna R637 miljoen gelewer het (Levin, 1961, 1105; Tegniek, 1963, 9).

Die gesonde toestand van ons land se ekonomie, nie net vandag nie, maar ook in die verlede, kan hoofsaaklik toegeskryf word aan die stabiliserende en stimulerende invloed wat die goudmynbedryf daarop gehad het en nog steeds het; en dit ten spyte van ons klein bevolking van ongeveer 3-4 miljoen blankes en 12-13 miljoen nie-blankes (Norval, 1962, 146 en 150-153). Busschau $(1961,11)$ sê: „... for our present purpose it is, I believe, sufficient to say that gold 
mining in South Africa remains in 1960, as it was in 1910, the largest single industry and generator of national income and provider of foreign exchange. Together with other forms of mining and agriculture it provides an expanding base for the growth of other forms of South African enterprise."

Sedert 1954 het Suid-Afrika jaarliks meer as die helfte van die nie-kommunistiese wêreld se goud geproduseer en in 1960 was ons aandeel meer as 60 persent. Norval $(1962,152$ 153) meen dat: ,Despite the relative decline in the contribution of gold to the national income, gold is still the one great stabilizing factor in the South African economy... Apart from the stabilizing influence that gold has on South African economy it is an all-prevailing catalytic agent transfusing all branches of the economy ... It is difficult to assess the importance of the gold-mining industry to the South African economy. It is the apex of the inverted pyramid on which the whole of the rest of the economy is halanced."

Die grootste gevaar vir die handhawing van ons huidige ekonomiese groeikoers lê in die feit dat ons goudafsettings nie hernieubare hulpbronne is nie. Ons toekomstige ekonomiese ontwikkeling sal so gerig moet word dat veral ons primêre en sekondêre nywerhede binne afsienbare tyd in staat sal wees om onafhanklik van die goudmynbedryf te bestaan en met konkurrente op internasionale vlak te kompeteer. Onder andere het Stratten $(1949,35$-36) reeds 15 jaar gelede daarop gewys dat ons land nywerhede nodig het waarop ons ekonomie gebou kan word wanneer ons goudmyne cendag uitgewerk is. Von Maltitz (1963, 16-17) meen dat ons goudafsettings ,die grootste enkele geluk (is) wat die Voorsienigheid aan ons geskenk het". Soos Von Maltitz (1963, 19-21) en ook ander deskundiges (Koch, 1962. 7; Lavine. 1962, 26-29; Busschau, 1960, 8-10) onlangs aangedui het, staan ons vandag reeds voor die probleem van sogenaamde "sterwende myne", grotendeels as gevolg van die diskriminerende belasting op goudmyne. In 1960 het die goudmynbedryf 'n belasting van byna $R 74$ miljoen op ' $n$ totale wins van omtrent $R 254$ miljoen, d.w.s. amper 30 persent, betaal (Anderson, 1961, 3). Met sodanige swaar belasting van ons vernaamste nywerheid kan goud nie juis op die doeltreffendste en konserverendste wyse met die oog op die toekoms ontgin word nie en word die bedryf 
ook nie juis aangemoedig om nuwe afsetting op te spoor en te ontgin nie.

In hierdie verband het mnr. E. H. Louw, destyds Minister van Ekonomiese Sake (1949, 39), die volgende gesê, maar sonder om die kwessie van belasting aan te roer: „We have in the past been living on gold. There is only one alternative, and that is the creation of an economy based on what is termed 'secondary' industry. Admittedly it will take a very long time to exhaust our gold resources, but if we do not plan ahead for that eventuality, the time will come when a future generation of South Africans will find itself with an economy largely based on gold mines, but without any gold in the mines."

Hierby moet ook in gedagte gehou word die waarskynlikheid dat wanneer ons goudmyne eendag sluit ons uraanproduksie, wat in 1960, naas goud se bydrae van meer as R500 miljoen, 'n bydrae van meer as $\mathrm{R} 100$ miljoen tot ons volksinkomste gelewer het, seker ook sal eindig, aangesien hierdie uraan 'n neweproduk van die goudmynbou is (Anderson, 1961, 3). Suid-Afrika is tans die derde grootste produsent van uraan en het ook die tweede grootste reserwe van uraan in die wêreld (Von Maltitz, 1963, 15-18).

Ek meen dat deeglik beplande ontwikkeling van fabriserende nywerhede gebaseer op ons aansienlike reserwes van yster-, mangaan-, chroom-, kopererts en steenkool die aangewese voorbehoedmiddel teen hierdie gevaar is. Saam met die redelike stabiele inkomste verkry uit ons diamant- en platinamynbedrywe, behoort ontginning van onedele delfstowwe en swaar-nywerhede wat daarop gebaseer is uiteindelik die fondament te kan vorm van 'n gesonde goudonafhanklike ekonomie. Produksie- en inkomstesyfers sedert 1910, asook beramings van beskikbare reserwes, dui aan dat ons land besonder ryk is aan die grondstowwe wat vir so 'n ontwikkeling nodig is, met uitsondering van kookskool en water, waaroor ek later nog meer sal sê. "Except that no natural oil and bauxite have been discovered, South Africa has at her disposal sources of almost all the base metals and non-metallic minerals of significance in world commerce and in modern industry, in addition to her exceptional gold and diamond mines" (Andrews en andere, 1962, 85-86). 
Volgens die jaarverslay van die Staatsmyningenieur 1962) was die totale verkoopswaarde van alle minerale en steenkool, in 1960 in Suid-Afrika geproduseer, meer as R850 miljoen. (Goud alleen was verantwoordelik vir meer as 60 persent van hierdie syfer. Met uitsondering van voorgeskrewe. materiaal en platina. waarvoor geen syfers deur die Staatsmyningenieur gegee is nie, was die verkoopswaardes van die volgende delfstowwe, in volgorde van produksiewaarde. almal meer as R2 miljon: stecnkool (R55 miljoen). diamante (R34. miljoen), asbes (R21 miljoen), koper (R21 miljoen), mangaanerts (R14 miljoen), kalksteen en dolomiet (R8 miljoen). ystererts (R7 miljoen), chroomertskonsentrate (R6 miljoen), ysterpiriet (R3 miljoen), herielertskonsentrate $(\mathrm{R} 2 \mathrm{miljoen})$ en sout (R2 miljoen). Von Maltitz (1963. 15$)$ gee R109 miljoen vir uraan en skat platina, waarvan die produksiesyfers nie gepubliseer word nie, op ongeveer R25 miljoen.

Volgens die Geologiese Opname $(1959,446-447)$ is ons vasgestelde en waarskynlike reserwes van steenkool (met inbegrip van kookskool) byna 80 miljard kleinton. Die waarskynlike kookskoolreserwe is ongeveer 6.5 miljard kleinton. Hierdie syfers verteenwoordig omtrent 35 persent van die reserwes in die suidelike halfrond en meer as 80 persent van die beraamde reserwes in Afrika (De Villiers. 1958, 18). Hierby moet onthou word dat die mynbou- en arbeidstoestande in Suid-Afrika so gunstig is dat ons steenkool goedkoper as enige ander land kan produseer. Petrick $(1961,419)$ wys egter daarop dat, vergeleke met ons totale steenkool- en ysterertsreserwes, die reserwes van kookskool, sover bekend, heperk is.

Die ontwikkeling van ons goudmynbou, ons yster-, staal-, ingenieurs- en ander nywerhede, asook die ontwikkeling van ons elektriese krag- en spoorwegstelsel, is alles moontlik gemakk deur die voorkoms van goedkoop steenkool (Norval. $1962,76)$. Saam met goudmynbou, is ons steenkoolmynbedryf vandag die fondanent warop die Republiek se industriële struktuur gebou is. Ons het geen enkele nywerheid waarin steenkool nie direk of indirek in belangrike rol speel nie (Kamer van Mynwese, 1954, 1-2).

Volgens die Geologiese Opname (1959, 333 en 337) kan uns ysterertsreserwes soos vulg ingedeel word: hoëgraadse erts ( 1.3 miljard ton), laegraadse erts ( 6 miljard ton), poten- 
siële erts $(2000$ miljard ton) en titaanhoudende ystererts $(2.2$ miljard toni. Die ysterertsafsettings in die omgewing van Sishen, met 'n maklik ontginbare reserwe van 1 miljard ton hoëgraadse erts, is sover bekend die grootste en rykste in Alrika.

Suid-Afrika is en van die grontste produsente van mangaanerts in die wêreld. Dit is 'n hoogs essensiële en strategiese delfstof, waarvan meer as 90 persent by die maak van staal gebruik word. Ons reserwe hoëgraadse mangaanerts is waarskynlik meer as 70 miljoen ton (Cenlogiese Opname, 1959, $24,5,251$ en 254).

Ons chroomertsreserwes is verreweg die grootste in die Westerse wêreld (Coetzee en Smit, 1961, 1050) en Suid-Afrika is tans die wêreld se derde grootste produsent van hierdie delfst of (Anoniem, 196lb, 12). Van alle chroomerts word 45 persent gebruik vir die maak van ferrochroom en 40 persent vir die mak van vuurvaste materiaal (Genlogiese Opname, 1959, 203 en 205).

Onder die vernaamste henodigdhede van 'n moderne industriële samelewing is 'n goeie voorraad kalksteen van geskikte gehalte. Kalksteen en sy derivaat, kalk, word waarskynlik tot "n groter mate as enige ander delfstof in die nywerheid gebruik (Geologiese Opname, 1959, 492). Groot hoeveelhede kalksteen is nodig vir die mak van sement (Andrews en andere, 1962. 118). Die Republiek se kalksteenreserwes is nie noukeurig bekend nie maar is sekerlik voldoende vir baie jare in die toekoms.

Die vernaamste gebruik van fluoriet is as smeltmiddel by die maak van staal en in dié opsig is dit 'n onontbeerlike nywerheidsgrondst of. Hoewel geen gepubliseerde beramings van reserwes beskikbaar is nie, is dit bekend dat hierdie delfstof baie algemeen in Transvaal voorkom en al sedert 1917 ontgin word. Met die oog op die ontwikkeling van ons staalnywerheid is hierdie mineraal besonder belangrik (Geologiese Opname, 1959, 565 en 573-574).

Voordat ons nou die fabriekswese behandel, is dit miskien interessant om net te noem dat daar 'n groot moontlikheid bestaan dat ons koperproduksie aansienlik sal toeneem met die ontginning van die groot laegraadse afsettings by Phalaborwa. Die kopermyn by Phalaborwa sal uiteindelik groter 
wees as die Nchanga-myn in Noord-Rhodesië, wat vandag as die wêreld se tweede grootste kopermyn gereken word (Tegniek, 1963, 1). Koper is tans die vernaamste onedele metaal wat ons uitvoer (Anoniem, 196lb, 13). Ook dien daar melding van gemaak te word dat Suid-Afrika tans die grootste wêreldprodusent van platina is en ook vierde op die lys van asbesprodusente staan (Geologiese Opname, 1959, 8 en 370).

Fabriekswese: Die fabriekswese sluit allerhande soorte nywerhede in, maar ek sal my hier beperk tot drie nywerhede wat basies vir die ontwikkeling van enige moderne geïndustrialiseerde ekonomie is en wat grotendeels op delfstowwe gebaseer is, nl. metaalverwerking, chemikalieëproduksie en kragopwekking. Hierdie drie nywerhede is basies in dié sin dat daar geen werklike industrialisasie en moderne landbou sonder hulle produkte kan bestaan nie.

(a) Metaalverwerking: Die verbruik per capita van yster en staal is een van die beste moderne indekse van industriële vooruitgang en militêre potensiaal (Van Royen en Bowles, 1952, 56; Woytinski en Woytinski, 1953, 1099). Voskuil $(1955,15)$ sê: „Iron and its alloys hold the central position in our modern economy. Iron is the key with which man multiplies his power to produce and increase his wealth"; en verder (bl. 4) : „Iron therefore assumes a major role among the metals; in fact, iron accounts for nine-tenths of all metal used. But iron is a product of iron ore and fuel a special fuel. The coke used to process the iron ore is made from high-quality coal, and coking coal is restricted in distribution. About one-fourth of the total fuels used in all manufacturing is used in this first step of converting iron ore into pig iron."

Volgens Norval (1962, 13 en 18) is 'n goed ontwikkelde yster- en staalnywerheid in Suid-Afrika net so basies vir die industrialisasie van ons ekonomie as in enige ander land. Sedert Yskor sy eerste staal in 1934 begin lewer het, het ons metaal- en ingenieursnywerhede werklik vir die eerste keer begin ontwikkel. Voor 1934, was die aandeel van die metaalen masjiennywerhede in die netto opbrengs van alle fabriserende nywerhede tussen 16 en 18 persent, maar sedert 1934 het dit geleidelik vermeerder tot oor 35 persent in 1955 (Bur. Sens. Stat., 1960, L-4). 
Vorval $(1962,17)$ meen dat dit moeilik is om die belangrike rol van Yskor in die Suid-Afrikaanse ekonomie te oorskat, veral as die basiese betekenis van staal en staalprodukte vir die landboukundige, fabriserende en mynbou-aktiwiteite van ons ekonomie in gedagte gehou word. In 1960 was die jaarlikse omset van die Yskorgroep byna R200 miljoen (Meyer, 196la, 56).

As gevolg van 'n tydelike afname in plaaslike aanvraag in 1959 en ten spyte van sterk buitelandse kompetisie, het Yskor toe daarin geslaag om bestellings ten bedrae van R24 miljoen uit 30 verskillende lande te kry — 'n bewys dat die Suid-Afrikaanse yster- en staalnywerheid inderdaad op die wêreldmark kan meeding en dit vanweë die kwaliteit van sy produkte en die besonder lae pryse daarvan (Krüger en andere, 1961, 1070). Volgens Coetzee en Smit (1961, 1052) behoort die Republiek ook met sy groot reserwes van mangaan- en chroomertse te kan uitsien na 'n sterk groeiende ferro-allooinywerheid in die toekoms. veral met die oog op die afname van hoëgraadse ertsreserwes in die res van die wêreld.

In dié verband stem ek ten volle saam met Norval (1962, 25) waar hy sê: „In its iron, steel, engineering and metal industries, South Africa possesses one of its greatest economic potentials of incomparable advantage for the development of an export trade. The development, physical and economic, that has taken place in the metal industries over the past twentyfive years is a clear demonstration of the enormous economic potential awaiting development and exploitation. The comparative advantage South Africa possesses in this field is unrivalled in any other part of the world. The vast deposits of iron, chrome and manganese ore, together with unlimited supplies of coal, the cheapest in the world, will in years to come constitute one of the greatest industrial sources of the world to supply world markets with a manifold of engineering products. It will not take very long before the Western world, heing drawn closer together through elimination of space and time, will become conscious, in particular, in view of the threat of Communism, of the vast economic potential of these reserves calling for exploitation. It will offer returns on and security in investment far in excess of that of gold.

„It would be extremely unwise for South Africa to enter 
into long-term contracts for the sale of its base minerals, even in a semi-processed state, thereby forfeiting the comparative advantage to others to exploit world markets for engineering products, which could be undertaken with equal facility and skill by getting the industries of the older countries, which do not enjoy such a vast comparative advantage, to join South Africa as partners in progress. When the Western world regains its perspective of Africa and when the boycott-mentality of the numerically rapidly emerging independent Africa States makes way for sanity, South African (sic) will become a vast cconomic bulwark for the upholding of the tenets of Western civilization."

Ook Meyer (196lb, 18) beklemtoon dat ons eerste prioriteitsdenke moet wees vir Suid-Afrikaanse nywerhede om alles moontlik te doen om die gefabriseerde produkte, gebaseer op ons betreklik goedkoop yster en staal, uit te voer eerder as om die grondstowwe uit te voer, soos ons tans nog doen.

(b) Chemikalieëproduksie: Die chemiese nywerheid is een van die oudste fabriserende nywerhede in ons land. Die totstandkoming daarvan was 'n direkte gevolg van die ontdekking van diamante en goud en die groeiende mynbou se aanvraag vir plofstowwe (Norval, 1962, 28; Liebenberg en Lambooy, 1961, 398). „African Explosives and Chemical Industries" is tans die grootste chemiese nywerheidsgroep in die suidelike halfrond en dit beskik oor die twee grootste springstoffabrieke en een van die grootste ureumfabrieke (terloops, die enigste in Afrika) in die wêreld, asook die grootste kunsmisfabriek in die suidelike halfrond (Anoniem, 1963a, 7).

Die moderne fabriekswese gebruik by die 3000 chemiese produkte, en so te sê alle nywerhede is direk of indirek afhanklik van chemiese produkte of prosesse wat deur die chemiese nywerheid ontwikkel is. Trouens, alle fabriserende lande, soos die Verenigde State en die Verenigde Koninkryk, het sedert die Tweede Wêreldoorlog as 't ware ,gechemikaliseer" geraak (Woytinski en Woytinski, 1953, 1183).

Die twee vernaamste nywerheidschemikalieë is swawelsuur en soda. Woytinski en Woytinski $(1953,1185)$ wys daarop dat "The output of sulphuric acid has always been considered a good business indicator, 'the grandfather of all indicators', since the acid is used in so many industries, and 
the hazard of storing it in quantity keeps the inventory of producers low and forces them to respond rapidly to changes in demand". 'n Land se graad van industrialisasie kan dus ook gemeet word volgens sy verbruik van swawelsuur (Geologiese Opname, 1959, 556).

Die springstofnywerheid het mettertyd ontwikkel van 'n nywerheid wat aanvanklik net die mynbou gedien het tot die huidige A.E. en C.I.-organisasie wat vandag 'n groot $\mathrm{krag}$ in ons industriële en landbou-ontwikkeling is. Liebenberg en Lambooy $(1961,407)$ meen dat ,Sulphuric acid manufacture, within African Explosives and Chemical Industries, provided the common factor for explosives production and wider diversification". Suid-Afrika is tans een van die wêreld se vernaamste swawelsuurprodusente. Die swawelsuur word gemaak uit piriet, wat hoofsaaklik 'n neweproduk van die goudmynbou is en waarvan die produksie in 1960 'n waarde van ongeveer R3.5 miljoen gehad het (Geologiese Opname, 1959, 556-557; Staatsmyningenieur, 1962, 28-29). Groot hoeveelhede swak swawelsuur word gebruik by die maak van superfosfaat, wat essensieel is vir die bewerking van ons fosfaatgebrekkige gronde.

Die toenemende verbruik van superfosfaat het mettertyd gelei tot 'n toenemende aanvraag vir gemengde bemestingstowwe, waarvan daar nou jaarliks ongeveer 400,000 ton verbruik word. Norval $(1962,29)$ sê: „No concern has rendered a greater service to mining and agriculture than this giant among giants". En dit word gedoen teen pryse wat vermoedelik die laagste in die wêreld is. Die waarde van die produkte van hierdie maatskappy is tans ongeveer gelyk verdeel tussen die mynbou aan die een kant en die landbou en sekondêre nywerhede aan die ander kant (Liebenberg en Lambooy, 1961, 409).

In 1950 en 1951 het twee ander belangrike chemiese nywerhede, wat direk op Suid-Afrikaanse delfstowwe gebaseer is, tot stand gekom, nl. Sasol en Foskor respektiewelik.

Sasol verteenwoordig die eerste poging in die suidelike halfrond om meer as net hitte en krag, deur verbranding, en staal, deur verkooksing, uit steenkool te fabriseer. Afgesien van die feit dat talle chemiese produkte uit Suid-Afrikaanse steenkool verkry kan word, soos onlangs deur Rousseau 
(1961, 377-378) aangedui is, lê die eintlike belangrikheid van Sasol daarin dat dit reeds 'n aansienlike bydrae tot ons behoeftes aan vloeibare brandst of maak en dat dit ook bewys van die moontlikheid lewer dat ons mettertyd selfversorgend sal kan word sover dit vloeibare brandstofhehoeftes betref.

De Villiers $(1958,12-13)$ wys daarop dat 87 persent van uns huidige energieverbruik uit steenkool afkomstig is en die res uit vloeibare brandstof. Hierdie 13 persent wat vloeibare brandstof verteenwoordig, is van groot ekonomiese en strategiese belang met die oog op die instandhouding van ons binnelandse vervoerwese. Hy sê dan ook: "Met die oog op hierdie feit verstout ek my om te beweer dat geen beplanning van die toekomstige ekonomiese ontwikkeling van SuidAfrika volledig sal wees sonder deeglik (sic) inagneming van die doeltreffendste benuttiging van hierdie uiters belangrike hodemskat, ons steenkoolreserwe nie, veral vir die vervaardiging van vloeibare brandstowwe". Rousseau (1961, 392) meen dat ,.The Sasol works have demonstrated that under the conditions which apply in the interior of South Africa, oil from coal is a feasible proposition". Verder meen Norval $(1962,34)$ dat "In the vast deposits of cheap coal South Africa possesses the basis for developing a large-scale chemical industry, which, next to iron and steel, should give the country a second large-scale industry of material comparative advantage in the years to come". Die vooruitsigte vir so 'n ontwikkeling sal natuurlik afhang van 'n groot binne- en buitelandse aanvraag vir die chemiese produkte wat, ongelukkig, nog nic daar is nie (Petrick, 1961. 413-414).

Die basiese en strategiese belangrikheid van die fabrisering van fosfaatkonsentraat met die oog op voedselproduksie het aanleiding gegee tot die stigting van Foskor in 195I (Norval, 1962, 36-37). Tot onlangs was ons geheel en al afhanklik van ingevoerde grondstowwe vir die produksie van bemestingstowwe. Die ontwikkeling van Foskor beloof om ons selfversorgend in hierdie opsig te maak. Dit word heraan dat die apatietafsettings van Phalaborwa voldoende is om die aanvraag vir fosfaat vir honderde jare te bevredig (Geologiese Opname. 1959, 463-466; Andrews en andere, $1962,118)$.

(c) Kragopwekking: Elektriese kragopwekking in Suid- 
Afrika was aanvanklik ook 'n direkte gevolg van die mynbou gebaseer op diamante, goud en steenkool en selfs vandag is die mynwese nog die vernaamste verbruiker van opgewekte elektrisiteit. In 1958-59 het die mynwese alleen meer as 50 persent van alle opgewekte krag gebruik en die ander nywerhede meer as 25 persent van 'n groot totaal van meer as 19 miljard kilowattuur (Bur. Sens. Stat., 1960, L-34; Andrews en andere, 1962, 6 en 19; Wellington, 1955, II, 176). (Kyk ook Fenwick en Torr, 1961, en Cheek en Gericke, 1961.)

Grootskaalse elektriese kragproduksie in ons land is gebaseer op direkte verbranding van goedkoop laegraadse steenkool en die gebruik van groot hoeveelhede water. Die groot kragstasies van Evkom is die grootste verbruikers van steenkool in Suid-Afrika (Geologiese Opname, 1959, 437). In 1956 het elektriese kragopwekking meer as 36 persent van ons steenkoolproduksie verbruik, en dit word beraam dat die kragstasies se verbruik in 1966 meer as 45 persent van die steenkoolproduksie sal wees (Andrews en andere, 1962, 106). In 1957 is meer as 12 miljard gellings rivierwater gebruik om elektrisiteit op die Rand op te wek (Eklund, 1962, 75), en dit word beraam dat teen die jaar 2000 Vaalrivierwater teen 'n tempo van 44 miljoen gellings per dag gebruik sal word om elektrisiteit op te wek (Olivier, 1962, 45). Hidroelektriese kragopwekking is skynbaar buite die kwessie vanweë die seisoenele karakter van ons riviere (Wellington, 1955, II, 179).

De Villiers (1958, 12-13) sê: „The availability and consumption of power and energy in general has become so important in the modern industrial era that one feels justified in saying that energy demand (or consumption) is, to-day, considered as a fair barometer of the degree of progressiveness of any country ..." Hy wys ook daarop dat die Suid-Afrikaanse energieverbruik van ongeveer 2.7 metrieke ton per capita in terme van steenkoolekwivalente in 1956, gebaseer op 'n bevolking van 13.9 miljoen, baie goed vergelyk met lande soos Engeland, Duitsland en Frankryk. Woytinski en Woytinski $(1953,971)$ wys ook daarop dat, afgesien van 'n noue korrelasie tussen die hoogte van industriële ontwikkeling en die verbruik van elektrisiteit, lande wat ryk aan waterkrag is meer elektrisiteit verbruik as dié waarin elektrisiteit uit staenkool 
verkry word. 'n Mens kan dus die gevolgtrekking maak dat Suid-Afrika al in 'n groot mate geïndustraliseer is.

landbou: Vanweë die lae reënval en swak grondgelialte in meeste dele van ons land, is Suid-Afrika aangewys op ekstensiewe boerdery en veral ekstensiewe veeboerdery (Van der Wath, 1963, 108; Sutton. 1951, 37; Kanthack, 1946, 23). (Grond vir so 'n opvatting vind ' $n$ mens in die feit dat maar ungeveer 10 persent van die ekonomies-aktiewe blankes in Suid-Afrika boer op plase wat altesaam omtrent 75 persent van ons land se totale uppervlakte beslaan (Van der Wath, 1963, 107; Andrews en andere, 1962, 57. Bowendien is ongeveer 85 persent van die land se oppervlakte natuurlike veld en Penzhorn $(1961,51)$ meen dat dit ook lank so sal bly. Van Eck $(1948,54)$ sê: .,'There are many areas in this country and in Africa which. in my opinion, should be left severely alone left to nature as much as possible".

In 1957 was daar 103,059 plase in Suid-Afrika, met 'n gesamentlike oppervlakte van $102,634,000$ morg, in vergelyking met 76,149 plase oor 'i gesamentlike oppervlakte van $90,550,000$ morg in 1918 (Bur. Sens. Stat., 1960, I-2). Volgens die Buro vir Sensus en Statistiek (1960, I-23--25) was die brutowaarde van landbouproduksie (in ronde syfers) in 1911, 1930, 1950 en 1958 respektiewelik R58 miljoen, R102 miljoen, R426 miljoen en R719 miljoen. Die aandele van akkerbou en veeteelt in hierdie opbrengste was respektiewelik R25 en R32 miljoen in 1911, R49 en R32 miljoen in 1930, R221 en R204 miljoen in 1950 en R364 en R354 miljoen in 1958. Tot 1958 het akkerbou en veeteelt dus so te sê kop aan kop gebly met hulle bydraes tot die volksinkomste.

Sedert 1918 het die brutowaarde van landbouproduksie vermeerder van ' $n$ gemiddelde van ongeveer RI per morg vir die land as geheel tot ongeveer $\mathrm{R} 7$ per morg in 1958. Volgens die gekombineerde indeks van produsentepryse van boerderyprodukte (Bur. Sens. Stat., 1960, H-29) blyk dat die reëlc gemiddelde opbrengs per morg in 1958 maar ongeveer R2.8 was. Die vraag ontstaan nou of die landbou as bron van volksinkomste werklik veel ontwikkel het en ook of dit nog veel meer sal kan ontwikkel. 'n Mens wonder of daar genoeg aandag gegee word aan die kostestruktuur van landbouproduksic. Dit is tog seker onekonomies om produkte waarvan 
die prys oortref word deur die produksiekoste, te produseer. om nie eers te praat van verdere ontwikkeling nie. Van der Wath $(1963,112)$ bevind dat ,... wat produksie en produsentepryse betref, die fisiese volume van produksie met 37 persent toegeneem het vanaf 1952 - 53, terwyl produsentepryse dalende neigings toon. Die vraag is dus hoe dit moontlik is dat in 'n produksie-onbeheerde bedryf soos ons landbou, produksietoenames kon plaasvind onder genoemde omstandighede". Andrews en andere $(1962,66)$ meen dat dit duidelik is dat verdere algemene uitbreiding van Suid-Afrikaanse boerdery nie net afhang van bevolkingsaanwas nie maar van 'n gestadige toename in reële inkomste, en hulle sê dan ook .Immediate market prospects being what they are, and costs outpacing prices, emphasis must inevitably fall on measures to reduce the costs of production".

Die boerderyskuld van R395 miljoen in 1958-59 was hesonder hoog in vergelyking met die totale kapitaalbelegging in landbou van R3,980 miljoen in 1959 (Van der Wath, 1963. 118; Andrews en andere, 1962, 57). Boerdery, en veral akkerbou en veeteelt, is essensieel vir die instandhouding van ons voedselproduksie, maar boerdery is ook 'n onderneming en die bedryf behoort dus, net soos enige ander bedryf, op 'n sakebasis beoefen te word (Van der Wath. 1963, 116).

Dit is voldoende vir die doel van hierdie oorsig om die kuste-aspek van ons landbou net aan die hand van ons mielieproduksie te illustreer. Bewerkte en braak saailande beslaan omtrent 10 persent van die totale plaasoppervlakte van SuidAfrika, d.w.s. maar omtrent vier persent van die land se oppervlakte. Hiervan is ongeveer 50 persent onder mielies en maar 15 persent onder koring (Whitmore, 1957, 9; Wellinginn. 1955. II. 3). Ten spyte hiervan was die brutowaarde van mielies in 1958 geproduseer maar ongeveer R102 miljoen, d.w.s. omtrent 28 persent van die totale brutowaarde van alle akkerbouprodukte, in vergelyking met die brutowaarde van geproduseerde koring wat meer as R39 miljoen was, d.w.s. meer as 9 persent van die totaal (Bur. Sens. Stat., 1960, (1-..23).

Afgesien hiervan wil dit voorkom asof mielies in ons land onekonomies geproduseer word, met 'n opbrengs per norg wat baie swak vergelyk met die opbrengste in Noord-en 
Suid-Amerika en selfs Australië, en teen 'n tempo wat nie deur die aanvraag geregverdig word nie, veral as die volgende 6 punte, onder andere, in ag geneem word:

(1) die feit dat ons mielieproduksie reeds die kerf bereik het wat teen die huidige verbruik eers in 1975 in aanvraag behoort te gewees het (Van der Wath, 1963, 120; Andrews en andere, 1962, 65);

(2) die Staatsubsidie van die mielieproduksie wat vir die huidige seisoen op ongeveer R10 miljoen beraam word (Die Transvaler, 28-2-63);

(3) die verswakking en erosie van ons grond deur mielieboerdery sonder rotasie (Wellington, 1955, II, 13 en 95-98; Penzhorn, 1961, 51);

(4) die nadelige invloed van droëlandakkerbou op grondwater- en afloopwateraanvulling;

(5) die feit dat ons koring en vleis moet invoer terwyl meer van hierdie twee produkte moontlik in sekere dele van die Hoëveld geproduseer kan word, waar tans voorkeur aan mielieproduksie gegee word (Van der Wath, 1963, 120 121; Andrews en andere, 1962, 60); en

(6) die wisselvalligheid en ontoereikendheid van die reënval, veral in die westelike dele van die Hoëveld (Whitmore, 1957, 22).

Whitmore $(1957,9)$ sê dan ook tereg: „Little further expansion in the area of maize cultivation can be envisaged in the near future; the only means of substantially increasing production is by improving the notoriously low yields". Sy is ook van mening dat mielieproduksie beperk behoort te word tot daardie streke wat 'n gemiddelde reënval van meer as 29 duim oor ten minste drie maande in die somer het (Whitmore, 1957, 12).

Sonder om al die faktore te behandel wat akkerbou in ons land en veral op die Hoëveld beïnvloed, is dit tog wenslik om hier kortliks daardie twee bodemhulpbronne te behandel waaraan ons land nie te ryk is nie en waarsonder akkerbou onmoontlik is, nl. grond en water. Ten spyte van die lewensbelangrikheid van hierdie twee hulpbronne, is statistiese gegewens oor die voorkoms en bruikbaarheid van gronde en oor die beskikbaarheid en verbruik van water skaars bekombaar. Daar jo twee moontlike redes vir hierdie oënskynlike 
veronagsaming of geringskatting van twee van ons vernaamste hulpbronne, nl. eerstens, die feit dat dit moeilik is om die waarde en verbruik daarvan in monetêre terme uit te druk en, tweedens, die waarskynlikheid dat daar te min besef word hoe belangrik hierdie twee hulpbronne vir ons land se voortbestaan en ontwikkeling is en die gevolglike gebrek aan kennis aangaande hulle.

Sover dit Suid-Afrikaanse gronde en water betref, is daar egter sekere dinge wat wel duidelik of bekend is en waarmee ook terdeë rekening gehou moet word, veral wanneer dit by akkerbou kom. Ten eerste kan ons met Sutton (1951, 37) saamstem waar hy sê: „The soil and water resources of a region are inseparably linked to one another, and a deterioration in one of them inexorably leads to a deterioration in the other, as is conspicuously illustrated in the case of soil erosion". Solank die grond met natuurlike plantegroei bedek is en die natuurlike toestand nie deur akkerbou of beweiding versteur is nie, is daar 'n natuurlike ewewig tussen faktore soos reënval, infiltrasie, verdamping, transpirasie, afloop, grondwaterstand en erosie. In hierdie verband speel die klimaat en die topografie natuurlik ook 'n belangrike rol (Wellington. 1955, II, 92-103; King, 1963, 24-25).

Ek wil u aandag beperk by die betekenis van sommige van hierdie faktore vir die akkerbou op die Hoëveld, waar die grootste persentasie van ons saailande voorkom, en veral die westelike dele waar ons met grenstoestande en ander beperkende aspekte te doen kry. Volgens Whitmore $(1957,6)$ is die klimaat gewoonlik die vernaamste beperkende faktor in die landboukundige potensiaal van streke wat gekenmerk word deur gekontrasteerde seisoene en 'n betreklike lae reënval. Sy is ook van mening $(1961,68)$ dat "land capability assessment cannot be based solely on those resources which are present in abundance. Equal significance attaches to those resources which are so deficient as to retard or restrict the scope for development, the so-called 'limiting factors' of the environment. This is especially true of so essential a resource as water; $\mathrm{no}$ other limitation is so prohibitive, or so generally experienced in South $\Lambda$ frica as lack of abundant water".

Die gemiddelde jaarlikse reënval vir Suid-Afrika as geheel is omtrent 18.5 duim per jaar (Whitmore, 1961, 69; 
Norval, 1962, 63). Ongeveer 78 persent van die land het 'n reënval van minder as 25 duim per jaar, wat algemeen beskou word as die minimum vir suksesvolle akkerbou in daardie dele wat somerreëns kry (Wellington, 1955, I, 239). Jordaan (1963, 83) wys daarop dat hoe laer die reënval van 'n streek is, hoe wisselvalliger is dit. Daarbenewens staan die doeltreffendheid van somerreënval in nou verband met verdamping en afloop (Wellington, 1955, I, 256). Onder Suid-Afrikaanse toestande verminder die afloop min of meer eweredig met die derde wortel van die reënval, mits ander omstandighede naasteby gelyk is. Dit beteken dat in dor streke die oppervlakafloop nog wisselvalliger as die reënval is (Jordaan, 1963, 83).

'n Ondersoek van die reënval in Suid-Afrika tussen 1904 en 1938 deur Levinkind het getoon dat vir byna 25 persent van hierdie periode van 35 jaar daar drougte oor meer as die helfte van die land was (Wellington, 1955, I, 264-266). Volgens hierdie analise kry 38 persent van die Republiek een droë jaar elke derde jaar en in die semi-ariede dele is die persentasie byna 50 . In hierdie verband sê Whitmore (1957, 22): "The occurrence of one or more intermittent droughts is in the course of the summer growing season must be regarded as a normal feature of the climate of the Highveld ..." Sy is ook van mening dat ,the amount of rain falling on a catchment sets the upper limit not only to the degree of intensification of dryland farming that may ultimately be achieved relative to drier or wetter catchments, but also to the volume of streamflow..." Met dit in gedagte wil ek dan die stelling waag dat ons moontlik reeds die boonste grens van intensifikasie van droëlandboerdery in sekere dele van die Hoëveld bereik het.

Ongeveer 90 persent van ons reënval infiltreer die grond, maar dit bly maar tydelik daar, aangesien die grootste deel daarvan betreklik gou deur verdamping en transpirasie na die atmosfeer terugkeer (Jordaan, 1963, 82; Norval, 1962, 63: Whitmore, 1961, 69). King $(1963,24)$ wys daarop dat wanneer die grond droog is, ten minste 'n halfduim reën nodig is om die grond vyf duim diep nat te maak. Hoogste infiltrasiekapasiteit is oor die algemeen geassosieer met goed gebalanseerde natuurlike plantegroei, maar akkerbou lei tot 'n 
vermindering in infiltrasiekapasiteit en in toename in verdamping (Whitmore, 1961, 72; King, 1963, 24-25). Navorsing het getoon dat meer as 50 persent van die reën wat op 'n mielieland val deur verdamping verlore kan gaan. Op die Hoëveld vind sodanige verdamping in die somer soms plaas teen 'n tempo van meer as een tiende van 'n duim per dag. In die somerreënvalstreke is daar periodes gedurende die nat seisoen waarin verdamping uit die grond heelwat meer as die reënval is (Wellington, 1955, I, 332). Wellington (1955, I, 241 en 257) wys ook daarop dat in die westelike dele van die Hoëveld die jaarlikse verdamping van vry wateroppervlakke drie tot vier keer so hoog as die jaarlikse reënval is.

Dit is ook belangrik om daarop te let dat die grootste deel van ons boerebevolking vandag van boorgatwater afhanklik is vir voortbestaan van die boerdery. Die vraag is of die fonteine, waarna so baie van die oorspronklike plase vernoem is, nie mettertyd opgedroog het as gevolg van die droëlandakkerbou wat geleidelik die Hoëveld ingeneem het en sodoende die natuurlike aanvulling van grondwater deur infiltrerende reënwater laat afneem het deurdat dit 'n kunsmatige toename in verdamping veroorsaak het nie. In 1948 was daar ' $n$ totaal van ongeveer 250 duisend boorgate in Suid-Afrika met 'n maksimum opbrengs van omtrent 150 miljard gelling (Wellington, 1955, I, 487). Omtrent 28 persent van hierdie gate was droog. Intussen het die opbrengs uit bestaande boorgate geleidelik afgeneem, en selfs die gemiddelde opbrengs uit nuwe boorgate is ook nie meer so hoog as wat dit vroeër was nie. Volgens die boorstatistiek van die Departement van Waterwese $(1960,9-10)$ het die 3618 gate wat in 1958-.59 geboor is minder as 2 miljoen gellings gelewer in vergelyking met oor die 11 miljoen gellings uit 992 gate geboor in 1931-32 en oor die 23 miljoen gellings uit 1145 gate geboor tussen 1903 en 1910. Voorlopige gegewens toon dat die aanvulling van grondwater 2 of meer persent van die reënval kan wees, maar dit wissel baie volgens die klimaat en die bodemgesteldheid (Jordaan, 1963, 91). 'n Aanvulling wat maar ongeveer 2 persent van die reënval bedra, kan seker maklik gekanselleer word deur 'n ewe klein verhoging van verdamping as gevolg van akkerbou, wat dan tot 'n geleidelike verlaging van die grondwaterstand sal lei. 
Afgesien van die beperkende invloed wat klimaat, veral sover dit reënval en verdamping betref, op akkerbou in die westelike dele van die Hoëveld het, is 'n verdere belangrike faktor die grond self. 'n Tekort aan fosfaat en humus is twee van die vernaamste gebreke van ons gronde (Wellington, 195., I, 334-335). Du Toit $(1954,490)$ wys daarop dat grondklassifikasie in Suid-Afrika betrekking moet hê op beide geologiese en klimaatsfaktore en verder (bl. 476) dat daar in die eerste plek 'n verskil gemaak moet word tussen sedentariese en getransporteerde gronde. In die westelike dele van die Hoëveld is die akkerbou gebaseer op hoofsaaklik ysterhoudende lateritiese gronde en getransporteerde sand. Veral in die noordwestelike Vrystaat is dit baie duidelik dat die akkerbou beperk is tot 'n deklaag van eoliese sand van variërende dikte en stabiliteit, en dat die sedentariese gronde van die streek heeltemal ongeskik is vir akkerbou (Wellington, 1955, I, 308-311 en 324-326; Du Toit, 1954, 482-483).

Die belangrikheid van afloopwater vir die toekomstige ontwikkeling van Suid-Afrika: Daardie klein persentasie van die reënval wat afloop, hou die vloei van ons riviere in stand en is daarom van die grootste belang vir die toekomstige ontwikkeling van ons land. As ' $n$ mens dit stel op tussen 8 en 9 persent van die gemiddelde jaarlikse reënval, beteken dit dat die vloei van ons riviere jaarliks met ongeveer 11,000 miljard gellings, of naasteby 19 miljoen morgveet $(575,000$ gellings $=1$ morgvoet), aangevul word. Hiervan word tans ongeveer 10 persent in groot damme opgevang, maar dit word as ekonomies moontlik beskou om uiteindelik jaarliks ongeveer 4000 miljard gellings, d.w.s. 7 miljoen morgvoet, wat omtrent 36 persent van die totale afloop verteenwoordig, in geskikte damme op te vang (Jordaan, 1963, 82 en 86; Whitmore, 1961, 74; Norval, 1962, 63-65).

Soos reeds aangedui, kry die boer aanvanklik 90 persent van die gemiddelde jaarlikse reënval as infiltrasie op sy grond. Afgesien hiervan gebruik Suid-Afrika jaarliks ongeveer 1700 miljard gellings water, waarvan alles stroomvloei verteenwoordig behalwe omtrent 150 miljard gellings, d.w.s. byna 13 persent, wat uit boorgate afkomstig kan wees. Sowat 87 persent van hierdie water, d.w.s. meer as 1500 miljard gellings, waarvan omtrent 134 miljard gellings uit grondwater- 
bronne afkomstig is, word gebruik vir die besproeiing van net meer as 900,000 morge grond, d.w.s. minder as een persent van ons totale plaasoppervlakte. Die res van die water, d.w.s. omtrent 13 persent, dien om ons myne, nywerhede, munisipaliteite en huishoudings aan die gang te hou (Jordaan, 1963, 87-89; Norval, 1962, 65; Bur. Sens. Stat., 1960, I-2).

Hoewel ons mynbou, nywerhede en munisipaliteite vandag nog maar betreklik min water in vergelyking met die landbou gebruik, behoort ons nou reeds, met die oog op ons land se aangewese nywerheidsontwikkeling, baie deegliker as ooit tevore te beplan vir 'n voordeliger en versigtiger gebruik en vir die instandhouding van ons waardevolle afloopwater. Die belangrikheid en noodsaaklikheid van sodanige beplanning is oor die afgelope 20 jaar al deur talle deskundiges beklemtoon (Kanthack, 1946; Frommurze, 1943, 1949, 1953; Hartley, 1948; Raikes, 1948; Mackenzie, 1949; Nel en Frommurze, 1949; Leslie, 1951; Sutton, 1951; R.O.N.H., 1951; Wellington, 1955; Schrader, 1959; Lineker, 1960; Rohertson, 1962a, 1962b; Midgley, 1962; Stander, 1962; Jordaan, 1963). Reeds byna 20 jaar gelede het Kanthack $(1946,19-20)$ al gesê: „My view at the time (1943) was, and still is, that a complete survey of water resources for the Union as a whole is the foundation for all social, economic, industrial and agricultural planning. It must be treated on a national basis and can only be undertaken by a single authority".

Stander $(1962,2)$ wys daarop dat die besproeiingsboerdery in Suid-Afrika maar slegs in 15 tot 20 persent van ons daaglikse behoeftes voorsien, in vergelyking met 25 persent gelewer deur besproeiingsboerdery in ander lande. Met die oog op die belangrikheid en noodsaaklikheid van beproeiingsboerdery, veral in ons digsbewoonde streek, wat van die afloopwater van die Vaalrivier se opvanggebied afhanklik is, meen beide Stander (1962, 2-3) en Jordaan (1963, 91-92) dat ons spaarsamer moet wees met die water wat ons vir besproeiing gebruik. Schrader $(1959,19)$, Lineker $(1960,12)$ en Stander (1962, 1-2) wys ook op die belangrikheid daarvan dat die verbruik van water in berekening gebring behoort te word by die vasstelling van die produksiekoste van landbouen nywerheidsprodukte, en laasgenoemde beklemtoon ook die noodsaaklikheid van 'n toename in die markwaarde van be- 
sproeiingsprodukte in terme van die hoeveelheid water wat met produksie verbruik word.

Die steeds toenemende aanvraag vir water uit die Vaalrivier vir munisipale. nywerheids- en landbougebruik skep) lans die vernaamste probleem by die volle ontginning van die rykdom van die Suid-Afrikaanse bodem en die ontwikkeling van sy potensiaal (Jordaan, 1963, 82; Robertson, 1962a, 5; 1962b, 5 en 27; Midgley. 1962, 125-126). Die hart van die Suid-Atrikaanse ekonomic word as 't ware aan die klop gehou deur water uit hierdie rivier soos tans beskikbaar gestel deur Vaaldam. Robertson (1962a, 5) sê: „In the Vaal River's catchment area South Africa will first be brought face to face with a situation where the demand for raw water from storage dams and the river bed exceeds the maximum supply which will be available during a series of three of four drought years such as those which withered the Highveld between the summers of 1930 and 1933.

"Then the prediction that water is one of the main limiting factors in the long-term development of our country will have become a practical reality in the most prosperous and highly developed region of South Africa".

In 1954 het wyle mnr. J. G. Strydom, destyds Minister van Lande en Waterwese, ' $n$ waterbegroting vir die Vaalrivier laat opstel wat tans nog as basis vir die benadering van ons waterprobleme in die opvanggebied van die Vaalrivier dien (Olivier, 1062. 45). Op grond van hierdie begroting kan ons 'n tekort van meer as 200 miljoen gellings per dag teen die jaar 2000 verwag en selfs al kan ons water van die Caledonrivier bykry, word die tekort nog op 128 miljoen gellings per dap beraam. Die begroting dui aan dat ons teen daardie tyd byna I miljard gellings water per dag, in dic gebied wat water uit die Vaalrivier gebruik, sal benodig. Die Hoofingenieur van die Randse Waterraad (Anoniem. 1962, 137) wys daarop dat dic daaglikse waterverbruik in die Vaalrivier se opvanggebied verlede jaar waurskynlik reeds meer as 600 miljoen gellings per dag was. Volgens Midgley (1962. 126 en 129) kan Vaaldam tans nie 'n groter onafgebroke onttrekking van meer as 575 miljoen gellings per dag. wat 44 persent van die gemiddelde jaarlikse afloop verteenwoordig, volhou nie. Die maksimum toelaatbare onttrekking 
is omtrent. 800 miljoen gellings per dag, d.w.s. omtrent 60 persent van die gemiddelde jaarlikse afloop; en dit is afgesien van hoe groot die dam miskien gemaak kan word, aangesien verdamping in boonste grens vir die opgaarkapasiteit van die dam bepaal. Huidige aanvare vir water nit Vaaldam oorskry reeds ver die laagste ophrengsgrens van 1.55 miljoen gellings per dag. wat gelyk is aan $36 . \overline{\text { j }}$ persent van die gemiddelde jaarlikse afloop. Gevolglik is dit nie moontlik om optimum watervoorsioning uit die dam to kry nie I Midgley. 1062. 129; Anoniem. 1962, 137 1.

Volgens in walerbegroting wal verlede jaar deur die landbouproefstasie by Vaalharts 11962, 7 ) opgestel is. sal die verbruik van hierdie knshare water op die skema vir nog lank waarskynlik konstant bly op lwna 150 miljoen gellings per dag. Volgens Stander (1962. H word die volle vloei van die Hartsrivier in die winter in stand gehou deur ongeveer 50 miljoen gellings ontollige water wat daagliks van die skema afloop en dreineer. Ander hesprociers verbruik waarskynlik saam meer as nog 70 miljoen gellings per dag. wat die totaal vir hreproeiing op onr die $20 n$ miljoen gellings per dag bring.

Hocwel dic verbruik van Vaalrivierwater vir besproeing dus skynbaar nie binne afsienbare tyd sal toeneem nie, neem die verbruik van water uit die rivier deur myne. nywerhede en munisipaliteite gestadiglik toc. en hier lê die eintlike probleem. Die onlangse rekordverskaffing van 247.5 miljoen gellings deur die Randse Waterraad op cen enkelc dag vestig die zandag baie pertinent op dic noodsaaklikheid van heplanning vir die toekoms (Anoniem, 1963b, 6). Die toekoms van Suidlfrika is baie nou gekoppel aan die instandhouding en ontwikkeling van die Witwatersrandse nywerheidakompleks. wat geheel en al van voldoende watervoorsiening uit die Vaalrivier afhanklik is (Rohertson. 1962h, 5 en 27 ). Midgley $(1962,125-126)$ is van mening dat ,... Whe Witwatersrand complex must continue to expand in order to generate the capital and provide the stimulus necessary for decentralization into areas where development may from some points of view he desirable but may not initially be economic.

The urban complex centred on the Witwatersrand is the heart and nerve centre of the whole subcontinent. It would 
be folly to allow its growth to be restricted by a shortage of water".

Aangesien meeste van die Vaalrivierwater tans vir besproeiing gebruik word, is dit seker logies om in die eerste plek ondersoek in te stel na die moontlikheid van meer ekonomiese verbruik van die water vir hierdie doel (Jordaan, 1963, 91-92; Schrader, 1959, 19; Lineker, 1960, 13; Leslie, 1960, 19; Sutton, 1960, 18). Op nywerheidsgebied word daar alreeds veel gedoen om gebruikte water vir hergebruik beskikbaar te stel, maar die vraag is of dieselfde van die besproeiingslandbou gesê kan word. Stander $(1962,3)$ meen dat die primêre verbruik van water miskien vir stedelike en nywerheidsontwikkeling gereserveer behoort te word, aangesien die annraag vir sulke doeleindes nie die landbou kan benadeel nie.

Uit die roorafgaunde is dit nou seker duidelik dat een van ons skaarste en daarom dus ook waardevolste bodemhulpbronne. nl. afloopwater, dic heperkende faktor by die doeltreffendste henuttiging van die rykdom van die SuidAfrikaanse hodem gaan wees. Dit is seker ook duidelik dat die noodsaaklikheid van 'n voldocnde voorraad afloopwater eerste in die geïndustrialiseerde Witwatersrandse kompleks gevoel gaan word. 'n Praktiese en realistiese oplossing van die landsbelangrike probleem waarvoor ons reeds te staan gekom het, lê seker in die toekenning van prioriteite by die verbruik van Vaalrivierwater wat nie op tradisionele aanspraak of politieke oorwegings gebaseer is nie, maar eerder op gesonde ekonomiese en natuurwetenskaplike beginsels.
P.U. vir C.H.O.
P. B. Ackermann.

\section{NASKRIF:}

Ek is baie dank verskuldig aan dr. D. P. Erasmus, prof. D. J. Viljoen en mnr. J. P. Duvenage vir advies gegee by die opstel van hierdie voordrag en vir die vestiging van my aandag op sekere resente publikasies waarvan ek nie bewus was nie. Ek is ook besondere dank verskuldig aan dr. D. P. Erasmus vir die kritiese deurlees van die tikskrif. 


\section{VERWYSINGS:}

Anoniem (1961a): Mining and engineering. S. Afr. Min. Engng. J., vol. 72 , nr. 3557 , bl. 4 .

Anoniem (196lb): South Africa's major base metals and minerals, S. Afr. Min. Engng. J., vol. 72, nr. 3557, bll. $11-13$ en 123.

Anoniem (1962): Rand Water Board. Future requirements of raw water. Chief Engineer's Report No. 3624, bll. 135-154.

Vaal - problems of a river's future. Vaal River Catchment Ass., Johannesburg, 161 bll.

Anoniem (1963a): A.E. \& C.I. - chemiese nywerheidskolos. Tegniek, jaarg. 15 , $\mathrm{nr}$. 2, bll. $6-7$ en 8 .

Anoniem (1963b): Water Board planning. Min. Industr. Rev., vol. 106, nr. 12 , bl. 6

Anderson, C. B. (1961): The organisation and management of the gold mining industry in South Africa, bll. 1-7. Trans. 7th Com monw. Min. Metall. Congr., S. Afr. Inst. Min. Metall., Johannesburg, $1388+$ xv bll.

Andrews, H. T., Berrill, F. A., De Guingand, F., Holloway, J. E., Meyer, F., Van Eck, H. J. en Van Schoor, A. M. (1962): South Africa in the sixties. S. Afr. Foundation, Johannesburg, 216 bll.

Buro vir Sensus en Statistiek (1960): Uniestatistieke oor vyftig jaar. Jubileumuitgawe 1910-1960. Staatsdrukker, Pretoria, 436 bll.

Busschau, W. J. (1960): Die nyuboubedryf se bydrae tot Unie. Die Mynwese, vol. 11, nr. 2, bll. 1-12.

Busschau. W. J. (1961): The economy of the Union of South Africa, bll. 9-12. Trans. 7th Commonw. Min. Metall. Congr., S. Afr. Inst. Min. Metall., Johannesburg. $1388+x v$ bll.

Cheek. B. J. en Gericke, M. R. (1961): The use of electric power by the gold mining industry, bll. 423-448. Trans. 7th Commonw. Min. Metall. Congr., S. Afr. Inst. Min. Metall., Johannesburg. $1388+x v$ bll.

Coetzee, J. J. en Smit, N. (1961): The production of ferro-alloys, bll. 1041-1053. Trans. 7th Commonw. Min. Metall. Congr., S. Afr. Inst. Min. Metall., Johannesburg, $1388+\mathbf{x v}$ bll.

Departement Waterwese (1960): Verslag van die Direkteur van Waterwese vir die tvdnerk 1 April 1958 tot 31 Mart 1959. Staatsdrukker. Pretoria, 29 bnl.

De Villiers. F. I. (1958): The on problem of South Africa in the light of world developments. Annu. Proc. ass. sci. tech. Socs. S. A fr., bll. 11-21.

Die Transvaler (1962): Mieliesurplus vir seisoen is 7 milj. sak. Jaarg. 26, nr. 127, bl. 1.

Du Plessia, D. H. C. (1961): Trananort in our time: service hased on knowledge and experience, bll. 85-89. Trans. 7th Commonw. Min. Mrtall. Congr., S. Afr. Min. Metall., Johannesburg, 1388 $+\mathrm{xv}$ bll.

Du Toit, A. L. (1954): The geology of South Africa, 3d ed. Edit. 
S. H. Haughton. Oliver \& Boyd. 611 bll.

Fihlunil. S. (). (1962): Industrial trende in water usage, bll. 73 -90. laal problems of a river's future. Vaal River Catchment Ass.. Johannesbury. 161 bll.

Fenwich. W. ent Torr. II. II. (1961): Electric power supply to the mining industry in the Transvaal and Orange Free State: its generation, transmission ant cost, bll. 453-187. Trans. 7th Commonw. Min. Metull. Congr.. \& Afr. Inst. Min. Metall., Johannesbury. $1388+x$ bll.

Frommurze. 11. $f$. (1943): Scientifie methods of waterfinding. Proc. yeol. Sw. S. Afr.. vol. Wh. bll. xxiii-xxxviii.

Frommurze. Il. F. (19:49): Receding underground water levels. S. Alr. J. Sci.. vol. th. bll, $51-5$;.

Frommurze. H. F, (1953): Hodrolugical regearch in arid and semiarid areas in the Union of South Africa and Angola, bll. 58-77. I'nesco. Reviews of research on arit zone hrdrology. Arid zonr program -... I.

Cieologiese Opnane (19.59): Die delfstunwe van die Unie van SuidAfrika. te uitgawe. Depl. Mynwese. Staatsdrukker. Pretoria, 627 bll.

Hartles. HI. (1918): Limiting factors in world development: what is poseible? Anum. Proc. ans rei. tech. Sors. S. Afr., bl. $42-53$.

Inrdaan. J. N. (1963): Die vourkons en die verbruiking:moontlikhede vall uns waterbronne. bll. 81 105. Referate gelewer by die lanrverqaderiag te Kaapstad. Ekonomiese Inst. (F.A.K.).

Kamer van Mvnwese (195t): Dir steenkoolmynbedryf in Suid-Afrikia. Die Munwese vol. 5. nr. 3. bll. 1--32.

Kinthack. F. F. (19.46): Industrial development in the Union of South Africa in relation to water resourcest. Annu. Proc. ass. sei. tech. Sors. S. Afr.. bll. 19 - 36 .

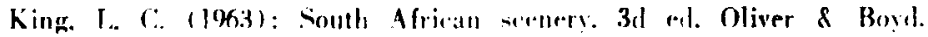
308 bll.

Korh. H. (: 11962): Dir nowl-akklikheid om nuwe numbon aan if mordig. Die Minwese. vol. 13. nr. 2. bll. 2--14.

hriiger. C. M.. Klein. F. en Warden. C. P. (1961): Iron and steel pro. fuction in South Airica. bll. 1057--1070. Trans. 7th Commonw. Min. Metall. Conur.. S. Mr. Inst. Min. Metall., Johannesburg. $1388+$ iv bil.

Jandbouproefstasie lis Vaalharts (1962): Veldtrust. Nov./Dex.. bl. 7.

lavine. J. (1962): Belasting on die aanderlhouer. Dir Mynweser. vol. 13. nr. 2. bll. $26-29$.

l.eslir. J. P. (1951): Water - the key to South African industrial progres. Optima, vol. I. ur. 3, bll. $7-11$.

1.eslir. I. P. (1960): Vote of thanks. Annu. Proce ass. sci. tech. Sucs. S. Afr.. bll. 18. -20

1.evin. J. (1961): Metallurgical research in South Africa. hll. 1103--1117. Trans. Th Commonw. Vin. Metall. Congr.. S. Afr. Inst. Min. Wetall.. Johamnesburg. $1388+$ xv bll.

l.jelwnhery. D). P. en lambomy. P. (1961): Fxplosives and allied che. 
mical industry with special refetence to mining. bll. 395-409.

Trans. Tth Commonw. Min: Metall. Congr., S. Afr. Inst. Min. Metall.. Johannesburg, $1388+x r$ bll.

lineket, A. If. (1960): The economic use of water. Anntu. Proc. aci. tech. Sucs. S. Afr., bll. 11-17.

lotw, E. H. (1949): Vote of thanks. Annu. Proc. ass. sci. tech. Socs. S. Afr., blt. $36-39$.

Mackenzie, L. A. (1949): Surface water - its measurement, control and use in Southern Africa. Afr. reg. sci.. Cont., Johannesburg, rol. II, Commun. A (f) 2 , bll. 53-55.

Veyer, F. (196la): The iron and steel industry of South Africa, bll. 49-36. Trans. Tth Commonw. Min. Metall. Congr.. S. Afr. Inst. Min. Metall., Johannesburg, 1388 + xv bll.

Veyer. F. (I\%, Ib): The Iscor group. Annu. Proc. uss. sci. tech. Socs. S. Afr., bll. 11--20.

Midyley, I). C. (1962): A water policy for the Vaal, bll. 125-134. Vaal problems of a river's future. Vaal River Catchment Ass., Johannesburg. 161 bll.

Vel. I. T. en Frommurze, H. F. (1949): The occurrence, location and exploitation of underground water in South Africa. Afr. reg. eci. Conf.. Johannesburg. vol. II. Commun. A (f) 3, bll. $56-60$.

Vorval, A. J. (1962): A quarter of a century of industrial progress in South Africa. Juta \& Co., 163 bll.

(1)ivicr. H. (1062): Water balance factors in the development of natural resources. bll. 12-45. Vaal - problems of a river's future. Vaal River Catchment Ass.. Johannesburg, 161 bll.

Penzhorn. K. H. W. (1961): Farm planning. S. Afr. geogr. J., vol. 13. bll. $19-.59$.

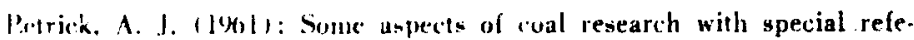
rence to ronditions in the Union of South Africa, bll. 411-420. Trans. Ith (.ommonw. Miu. Metall. Compt... S. Afr. Inst, Min. Metall. Johamenhurr. $1388+\mathrm{xy}$ bll.

Raikes. I1. R. 119181: liquid fuel from coal. Annu. Proc. ast. acci. tech. Sors. s. lfr.. bll. $20 \cdots-38$. . :

Anthertson. T. (.. (1962a): Foreword. bl. 5. Vaal $\rightarrow$ problems of a ripri: future. Vaal River Catchment Ass. Iohannesburg, 16l bll.

Rebiertaon. T. C., (1062b): Floods of the Vaal ran be harvested. Veld. : trat. Nov, Des., bll, 1-5.en-27.

R.O.N.II. 19511: Raad vir lie Ontwikkeling van Natuurlike Hulpdrnnne. 3r jiatrerslag. Dept. Handel en Nywerheid. Staatsdrukker, Preloria.

Ronssedu, P. F. I|Whl): The conversion of South African low-grade conal to oil and rlemicals, hll. 375--392. Trans. 7th Commonw. Vin. Metall. Coingr.. S. Mr. Inst. Min. Metall. Johannexbura $13 \mathrm{Bg}+\mathrm{xv}$ bll.

Sehrader, H. (1959): Iocal government and the Associated Scientific nnil Technical Societies of South Africa. Annu. Proc. ass. sci. tech. Socs. \$. Afr., bll. 11-25. 
Sehumann, C. G. W. (1963): Natuorlike hulpbronne en volkswelwaart, bll. :-21. Referate gelewer by die. Jaarvergadering te Kaapstad. Ekonomiese Inst. (F.A.K.).

Schumann, C. G. W. Franzen, D. G. en De Kock, G. (1957): Ekonomie. Universiteitsuitgewers en Boekhandelaars, 770 bll.

Stantsmyningenieur (1962): Jaarverslag insluitende verslae van die Staatsmyningenieur en die Geologiese Opname vir die jaar geeindig 31 Desember 1960. Dept. Mynwese, Staatsdrukker, Pretoria, 105 bll.

Stander, G. J. (1962): Important philosophies in the beneficial use of water and industrial effluent management. W.N.N.R.-publikasie, Pretoria, bll. $1-7$.

Stratten, T. P. (1949): The relative claims of mining and secondary industry for the limited resources of South Africa. Annu. Proc. ass. sci. tech. Socs. S. Afr., bll. $21-36$.

Sutton, W. G. (1951): Water as a basic factor in the development of the natural resources of South Africa. Annu. Proc. ass. sci. tech. Socs. S. Afr., bll. 17-39.

Sutton. W. G. $(1960)$ : Vote of thanks. Annu. Proc. ass. sci. tech. Socs. S. Afr., bll. 17-18.

Tegniek (1963): 1962: Nuwe rekordjear vir S.A. goud. Tegniek, jaarg. 15, nr. 3, bl. 9.

Van der Wath, J. G. (1963): Die landbou, bll. 106-123. Referate gelewer by die Jaarvergadering te Kaapstad. Ekonomiese Inst. (F.A.K.).

Van F.ck, H. J. (1948): Vote of thanks. Annu. Proc. ass. sci. tech. Socs. S. Afr. bll. 53-56.

Van Roven. W. en Bowles, O. (1952): The mineral ressurces of the world. Prentice-Hall, 181 bll.

Von Maltitz A. A. (1963): Mvnbou, bll. 13-21. Referate gelewer by die Jaarvergadering te Kaapstad. Ekonomiese Inst. (F.A.K.).

Voskuil, W. H. (1955): Minerals in world industry. McGraw-Hill, 324 bll.

Wellington, J. H. (1955): Southern Africa. Cambridge Unirersity Press. Vol. I, 528 bll., Vol. II, 283 bll.

Whitmore. J. S. (1957): The influence of climatic factors on the agricultural development of South Africa. S. Afr. geogr. J., rol. 39 , bll. $5-25$.

Whitmore, J. S. (1961): Agrohydrology. S. Afr. geogr. J., vol. 43 , bII. $68-74$.

Wovtinski, W. S. en Woytinski, E. S. (1953): World population and production. Twentieth Century Fund, New York, 1250 bll. 